\title{
CLINICAL PROFILE OF ACUTE BACTERIAL MENINIGITS AND OUTCOME
}

\author{
G. V. Ramadevi ${ }^{1}$, A. Venkatashetty른 Sardar Sulthana ${ }^{3}$, M. Suhasini ${ }^{4}$, V. V. Ratnakar Reddy ${ }^{5}$
}

\section{HOW TO CITE THIS ARTICLE:}

G. V. Ramadevi, A. Venkatashetty, Sardar Sulthana, M. Suhasini, V. V. Ratnakar Reddy. "Clinical Profile of Acute Bacterial Meninigits and Outcome". Journal of Evolution of Medical and Dental Sciences 2015; Vol. 4, Issue 05, January 15; Page: 862-871, DOI: 10.14260/jemds/2015/123

ABSTRACT: OBJECTIVES: To study the clinical profile of ABM and analyse the differences in clinical presentation among young infant, toddler, compared to school going children. And to find out the bacteriological profile and sensitivity pattern of ABM. MATERIALS AND METHODS: The present study is a prospective non-randomized single arm study. Children with the diagnosis of ABM admitted to the department of Pediatrics Govt. General Hospital, Kurnool from January 2013 to October 2013 are included in the study. Clinical details of all patients were recorded CSF was analysed by routine biochemical methods, and microbiological studies on special media. The children were managed as per the standard protocols. RESULTS: In a study period of 1 year During the study period 74 children (1.5\% of all admissions) satisfied the criteria of ABM in early childhood;. The incidence of Acute Bacterial Meningitis was $1.45 \%$ of total Pediatric admissions. Of the 74 cases 25 died. Mortality rate was 33.79\%.mortality observed was more in less than one year of age. Chief presentation was high fever, refusal of feeds, altered sensorium and seizures. The final etiological diagnosis (as per LAT and/or cultures) were 32 cases are positive for culture and sensitivity of ABM and Biochemically and Cell count wise 74 cases are positive for ABM. CSF has grown pneumococci in $8(25 \%)$ cases, Coagulase positive Staph. Aureus in $3(9.38 \%)$ cases, Coagulase negative Staph. Aureus in $3(15.63 \%)$ cases, Nesseria Meningitides in $3(9.38 \%)$, Klebsiella in $4(12.50 \%)$ cases, E coli, Enterococci and Pseudomonous in $9(28.13 \%)$ The outcome in the present study with respect to death is $33.78 \%$ and $45.95 \%$ of patients Survived with complications, $20.27 \%$ of patients survived without complications. CONCLUSION: The incidence and Mortality were significantly high in low socio economic group. The incidence and mortality was high in lesser age group. Mortality is very high with high CSF protein and low sugar levels. Pneumococci and coagulase negative staphylococci are predominant causes of morbidity and mortality associated with ABM.

KEYWORDS: Bacterial Meningitis, CSF Analysis Morbidity Mortality.

INTRODUCTION: Acute Bacterial meningitis (ABM) is an important cause of morbidity and mortality in children in developing countries. In a recent multicentre survey in India, ABM constituted 1.5\% of admissions to pediatric wards, and the mean case fatality rate was $16 \% .{ }^{1}$ The frequency of sequelae developing countries is probably greater than the $8-40 \%$ reported for developed countries. ${ }^{2}$ The community incidence of ABM in India is exactly not known. The exact etiological diagnosis is often not possible, because of poor culture facilities.3,4 The three organisms commonly associated with ABM in early childhood in western countries are Hemophilus influenzae type $b, S$. Pneumoniae and Neisseria meningitidis. However, the etiology may vary in different parts of the world and among different regions of the same country. ${ }^{5} \mathrm{ABM}$ is more severe and, without treatment, $50 \%$ fatal. Mortality is high due to lack of awareness of the condition, non-specific symptoms, delay in seeking medical help and catastrophic nature of illness. It is a medical emergency which requires prompt treatment. The present study is undertaken to estimate frequency of ABM in children in hospital 


\section{CASE REPORT}

admissions, to describe clinical and diagnostic features, and to analyze mortality, complications and its sequelae in relation to clinical / etiological factors.

MATERIALS AND METHODS: This prospective descriptive analytical and interventional clinical study was done on children above 1 month of age admitted to pediatric department Govt. General Hospital, Kurnool, from January 2013 - October 2013. The children are mostly referred from peripheral hospitals and are brought late in critically sick condition. Study population includes a total of 246 cases of clinically suspected ABM were screened and of them 74 cases fulfill all the inclusion criteria which formed the basis of the present study. Study was conducted over a period of 10.months from January 2013 - October 2013. Inclusion criteria includes Presence of fever, altered sensorium, seizures, neck stiffness, coma, irritability, cranial nerve involvement, headache, vomiting, bulging anterior fontanel, etc. and One or more of the following laboratory criteria- CSF Glucose less than 40 $\mathrm{mg} / \mathrm{dl}$. . CSF protein greater than $50 \mathrm{mg} / \mathrm{dl}$. CSF cell count greater than $50 \mathrm{~mm}^{3}$ or PMNs predominate, positive CSF culture. Study protocol includes 74 confirmed cases Among 246 clinically suspected cases of ABM were enrolled for the study. Of this biochemically and pathologically 74 cases are confirmed, and culture was positive in 32 cases. Information was recorded on a structured Proforma by questionnaire method. Information related to age, sex, duration of symptoms, past history, immunizations history, developmental history, nutrition history, antenatal, natal, post natal history, treatment history, socio economic status of parents, etc was considered.

A thorough clinical examination was done on the day of admission and findings recorded specimens like blood, CSF, urine were collected at the time of admission, CSF was collected as soon as child's cardio pulmonary status was stabilized.

All the cases initially started on combination of antibiotics ceftriaxone and amikacin as per recommended doses, antibiotics were subsequently changed if necessary based on culture and sensitivity and response to treatment. Duration of therapy was decided depending on response to treatment. Supportive therapy included intra venous fluids, tube feeds, oxygen therapy, anticonvulsants, blood transfusions, manniotal, $3 \% \mathrm{Nacl}$, oral glycerol, ventilatory support depending on the need of the individual case. Progress of the child was monitored at least thrice a day throughout hospital stay and the complications were managed accordingly as and when arose. Cases were followed up to determine final outcome as death, survival, survival with squeale. The children who are admitted were done with the Complete blood counts, Hemoglobin, ESR \& CSF analysis - lumber puncture was done under strict asepsis using autoclaved needle by standard method. CSF was collected in 3 separate sterile bottles one for microscopy, one for biochemical analysis and one for grams stain and culture. for culture CSF was immediately plated on mac conkey, blood and chocolate agar plates plates were incubated at 37 degrees for minimum period of $24 \mathrm{hrs}$, positive cultures were subjected to antibiotic sensitivity. X-RAY, NEUROSONOGRAM, C T Scan, MRI as per need. The study was approved by the Ethics Committee of the hospital and informed consent of the parents was obtained.

RESULTS: A total of 5704 patients admitted in pediatric ward of Govt. General Hospital, Kurnool, from January 2013 - October 2013 out of which 246 cases are suspected as meningitis are personally studied are reviewed in light of accumulated literature for Acute Bacterial meningitis. However only 74 cases are meeting the criteria of Acute Bacterial Meningitis. The incidence of Acute Bacterial Meningitis was $1.45 \%$ of total Pediatric admissions. Of the 74 cases 25 died. Mortality rate was 


\section{CASE REPORT}

$33.79 \%$.mortality observed was more in less than one year of age. Out of 74 cases of confirmed Acute Bacterial Meningitis were studied out of this 45 (60.81\%) case were Males and 29 (39.19\%) were females. Male to Female ratio is 1.5: 1. Total deaths were $25(33.79 \%)$ of them $17(68 \%)$. Males and $8(32 \%)$ are female. Out of 74 cases $49(66.22 \%)$ are between the age group of 1Month - 1Year, 14 $(18.9 \%)$ are between the age group of 1 year - 3 Year, $8(10.8 \%)$ are between the age group of 3year 6 Year, 3 (4.05\%) are above 6 year. Mortality age wise are 18 (36.73\%), 5 (35.71\%) 2 (25\%), 0(0\%) of respective admissions.

In the study it is observed that the mortality in lower class is $12(48 \%)$ cases out of 40 cases, upper lower class is $8(38 \%)$ cases out of 24 cases, lower middle class is $2(8 \%)$ cases out of 5 cases, upper middle class is $1(4 \%)$ cases out of 3 cases, upper class is $2(8 \%)$ cases out of 2 cases.

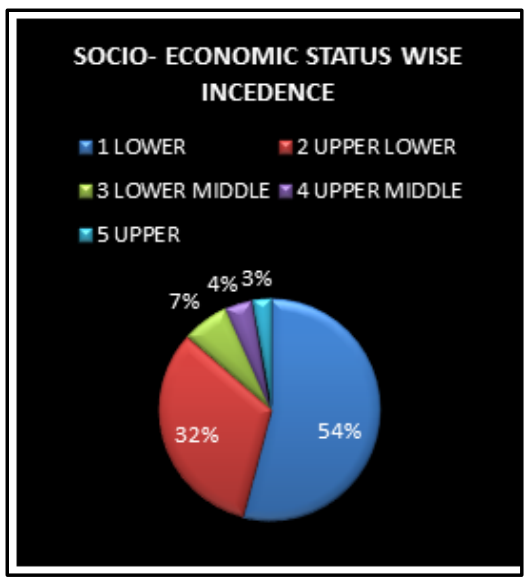

Figure 1

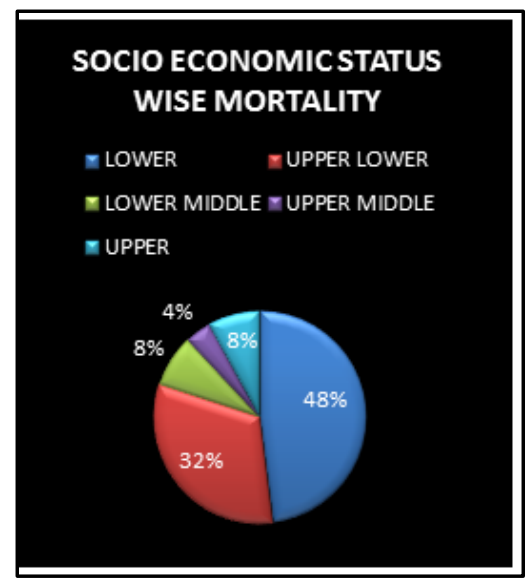

Figure 2

Among the various presenting symptoms fever was present in 72 case, altered sensorium/ coma in 70 cases, convulsions are present in 52 cases vomitings are present in 54 cases. Stiff neck is present in 42 cases. Head ache was complaint after 4 years of age.

\begin{tabular}{|c|c|c|c|}
\hline Sl. NO & SYMPTOMS AND SIGNS & SYMPTOMS AND SIGNS & $\mathbf{\%}$ \\
\hline 1 & FEVER & 72 & 97.30 \\
\hline 2 & ALTERED SENSORIUM/COMA & 70 & 94.59 \\
\hline 3 & SEIZURES & 62 & 83.78 \\
\hline 4 & NAUSEA/VOMITINGS & 54 & 72.97 \\
\hline 5 & STIFF NECK & 42 & 56.76 \\
\hline 6 & HEAD ACHE & 11 & 14.86 \\
\hline 7 & HYPOTENSION & 10 & 13.51 \\
\hline 8 & RASH & 7 & 9.46 \\
\hline 9 & BLEEDING MANIFESTATION & 6.76 \\
\hline
\end{tabular}

In the study it has been observed that mortality and morbidity is high those cases who have less than $40 \mathrm{mg} / \mathrm{dl}$. Deaths in cases who have CSF glucose less than $40 \mathrm{mg} / \mathrm{dl}$ is 15 cases(60\%),and cases who have CSF glucose greater than $40 \mathrm{mg} / \mathrm{dl}$ is 10 cases (40\%). 


\begin{tabular}{|c|c|c|c|c|c|}
\hline Sl. NO & C S F SUGAR & NO.OF CASES & PERCENTAGE & DEATHS & PERCENTAGE \\
\hline 1 & Less than $20 \mathrm{Mg}$ & 7 & 9.46 & 3 & 42.85 \\
\hline 2 & $21-30 \mathrm{mg} / \mathrm{dl}$ & 15 & 20.27 & 8 & 53.33 \\
\hline 3 & $30-40 \mathrm{mg} / \mathrm{dl}$ & 23 & 31.08 & 4 & 17.39 \\
\hline 4 & $40 \mathrm{mg} / \mathrm{dl}$ & 29 & 39.19 & 10 & 34.48 \\
\hline \multicolumn{7}{|c|}{ Table 2 } \\
\hline
\end{tabular}

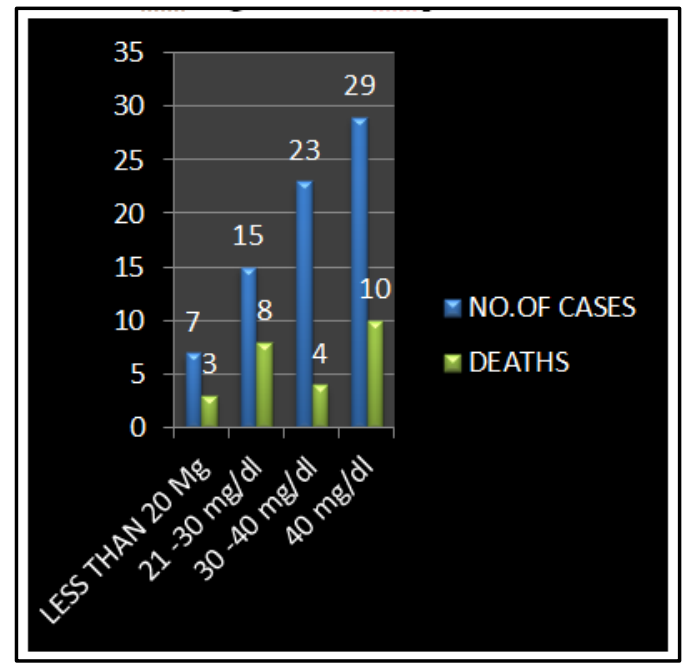

Figure 3: CSF sugar level

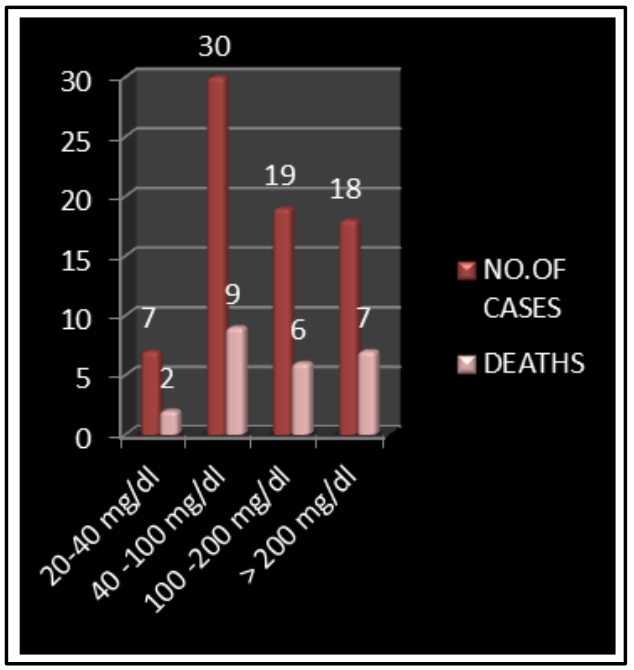

Figure 4: CSF protein level

In the study it has been observed that mortality and morbidity is high those cases who have CSF protein greater than $40 \mathrm{mg} / \mathrm{dl}$. Deaths in cases those who have CSF protein greater than 40 $\mathrm{mg} / \mathrm{dl}$ are 23 cases(92\%), and cases who have CSF protein less than $40 \mathrm{mg} / \mathrm{dl}$ is 2 cases(8\%).

\begin{tabular}{|c|c|c|c|c|c|}
\hline Sl. NO & C S F PROTEIN & NO.OF CASES & PERCENTAGE & DEATHS & PERCENTAGE \\
\hline 1 & $20-40 \mathrm{mg} / \mathrm{dl}$ & 7 & 9.46 & 2 & 28.57 \\
\hline 2 & $40-100 \mathrm{mg} / \mathrm{dl}$ & 30 & 40.54 & 9 & 30 \\
\hline 3 & $100-200 \mathrm{mg} / \mathrm{dl}$ & 19 & 25.68 & 6 & 31.57 \\
\hline 4 & $>200 \mathrm{mg} / \mathrm{dl}$ & 18 & 24.32 & 7 & 38.88 \\
\hline \multicolumn{7}{|c}{ Table 3 } \\
\hline
\end{tabular}

In the study it has been observed that mortality and morbidity is high in those cases who have CSF cell count greater than 50 cell. Deaths in cases those who have CSF cell count greater than 50 cell are 17 (68\%) cases, and cases who have CSF cell count less than 50 are 8 (32\%) cases. 


\section{CASE REPORT}

\begin{tabular}{|c|c|c|c|c|c|c|c|}
\hline Sl. NO & $\begin{array}{c}\text { TOTAL } \\
\text { COUT }\end{array}$ & SURVIVAL & $\%$ & $\begin{array}{c}\text { SURVIVAL } \\
\text { WITH SEQUELE }\end{array}$ & $\%$ & DEATH & $\%$ \\
\hline 1 & $<50$ & 10 & 13.51 & 13 & 17.57 & 8 & 10.81 \\
\hline 2 & $50-100$ & 3 & 4.05 & 11 & 14.86 & 7 & 9.46 \\
\hline 3 & $>100$ & 1 & 1.35 & 11 & 14.86 & 10 & 13.51 \\
\hline
\end{tabular}

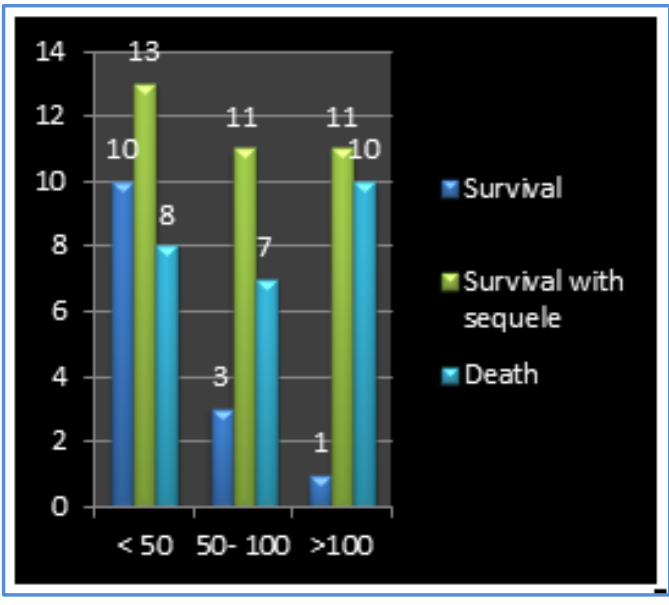

Figure 5

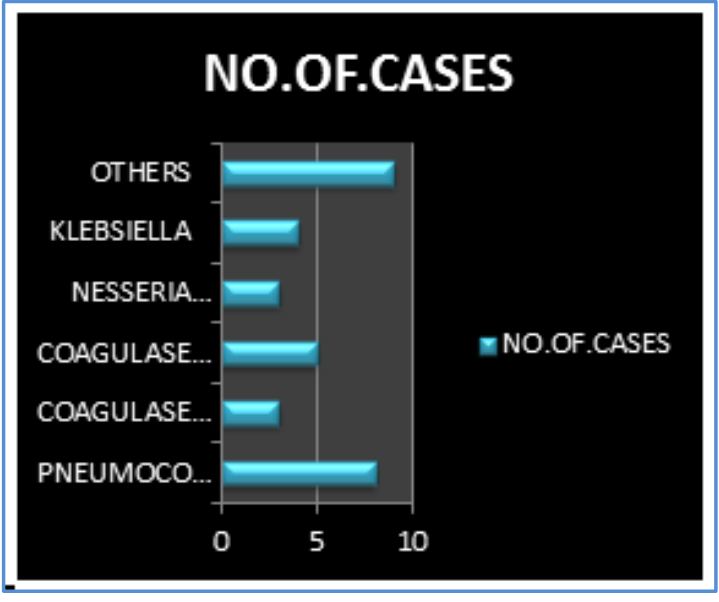

Figure 6

In the present study it has been observed that out of 246 cases suspected meningitis clinically have been sent for culture and sensitivity it has been observed that 32 cases are positive for culture and sensitivity of ABM and biochemically and cell count wise 74 cases are positive for ABM. It has been observed that pneumococci are $8(25 \%)$ cases, CPS are $3(9.38 \%)$ cases, CONS are $3(15.63 \%)$ cases, Nesseria Meningitides are $3(9.38 \%)$ Klebsiella are $4(12.50 \%)$ cases. Others- E coli \& Enterococci PSEUDOMONAS are 9(28.13\%). In grams stain of CSF only 1 is positive for diplococci.

\begin{tabular}{|c|c|c|c|}
\hline Sl. NO & ORGANISMS ISOLATED & NO. OF. CASES & PERCENTAGE \\
\hline 1 & PNEUMOCOCCI & 8 & 25.00 \\
\hline 2 & COAGULASE POSITIVE STAPHYLOCOCCI & 3 & 9.38 \\
\hline 3 & COAGULASE NEGITIVE STAPHYLOCOCCI & 5 & 15.63 \\
\hline 4 & NESSERIA MENINGITIDES & 3 & 9.38 \\
\hline 5 & KLEBSIELLA & 4 & 12.50 \\
\hline 6 & OTHERS Table 5 & 9 & 28.13 \\
\hline \multicolumn{2}{|c}{} \\
\hline
\end{tabular}

The outcome in the present study in respect to mortality is 25 cases (33.78\%) and Survival with sequelae are 34 cases (45.95\%). Survivals without sequelae complication are 15 cases (20.27). 


\section{CASE REPORT}

\begin{tabular}{|c|c|c|c|c|}
\hline \multirow{2}{*}{ OUT COME } & \multicolumn{2}{|c|}{ PRESENT STUDY[74] } & \multicolumn{2}{c|}{ PANDIT ET AL[4] } \\
\cline { 2 - 5 } & NUMBER & PERCENTAGE & NUMBER & PERCENTAGE \\
\hline DEATH & 25 & 33.78 & 17 & 31.48 \\
\hline Survived with sequelae & 34 & 45.95 & 23 & 42.59 \\
\hline survived without sequelae & 15 & 20.27 & 14 & 25.93 \\
\hline \multicolumn{3}{|c|}{ Table 6 } \\
\hline
\end{tabular}

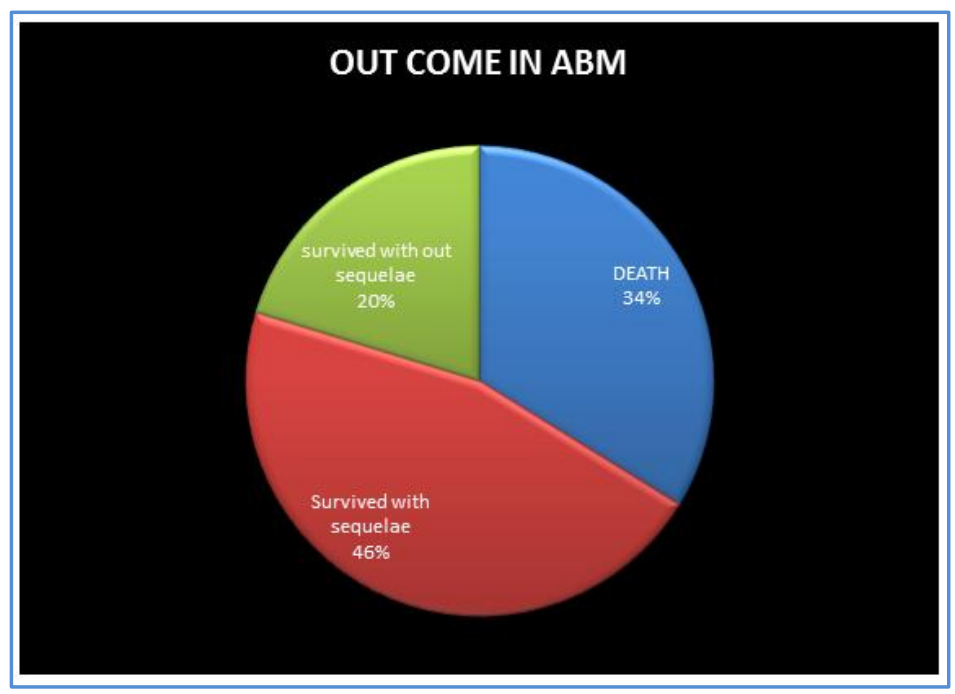

Figure 7

\begin{tabular}{|c|c|c|c|c|c|c|c|c|}
\hline $\begin{array}{c}\text { Age } \\
\text { group }\end{array}$ & \multicolumn{2}{|c|}{ CASES 74 } & \multicolumn{2}{c|}{ STAPHYLOCCCI } & $\begin{array}{c}\text { Streptococcus } \\
\text { pneumoniae } \\
\text { meningitides }\end{array}$ & $\begin{array}{c}\text { Neisseria } \\
\text { KLEBSIELLA }\end{array}$ & $\begin{array}{c}\text { Others } \\
\#\end{array}$ \\
\hline & $\begin{array}{c}\text { Probable* } \\
\mathrm{n}-74\end{array}$ & Confirmed ${ }^{* *} \mathrm{n}-32$ & CONS & CPS & S P & N M & K & 0 \\
\hline & 74 & 32 & 5 & 3 & 8 & 3 & 4 & 9 \\
\hline $1 \mathrm{M}-1 \mathrm{Y}$ & 49 & 17 & 4 & 3 & 2 & 0 & 1 & 7 \\
\hline $1 \mathrm{Y}-3 \mathrm{Y}$ & 14 & 9 & 1 & 0 & 3 & 2 & 1 & 2 \\
\hline $3 \mathrm{Y}-6 \mathrm{Y}$ & 8 & 4 & 0 & 0 & 1 & 1 & 2 & 0 \\
\hline $6 \mathrm{Y}-18 \mathrm{Y}$ & 3 & 2 & 0 & 0 & 2 & 0 & 0 & 0 \\
\hline
\end{tabular}

Table 7: Age-Wise Distribution Of Cases With Causative Organisms

*PROBABLE CASE: A SUSPECTED CASE WITH CSF LEUKOCYTOSIS OF > 50 WBC/CMM, PROTEIN $>100 \mathrm{MG} / \mathrm{DL}$, OR GLUCOSE < $40 \mathrm{MG} / \mathrm{DL}$;

** CONFIRMED CASE: A PROBABLE CASE WITH A POSITIVE BACTERIAL ISOLATE IN CSF CULTURE \# OTHERS: GRAM NEGATIVE BACILLI, E COLI, ENTEROCOCCI AND PSEUDOMONAS. 


\section{CASE REPORT}

DISCUSSION: The present study was conducted in the Department of Pediatrics, Government General Hospital, Kurnool, during period from January 2013 to October 2013. Out of which 246 cases were suspected as meningitis, studied and reviewed in light of accumulated literature for Acute Bacterial meningitis. However only 74 cases are meeting the criteria of Acute Bacterial Meningitis.

The incidence of ABM observed in 10 months period of our study was $1.46 \%$ of total Pediatric admissions of age group greater than one month. PANDIT et al (2002) cited the incidence of $1.5 \%$ of admissions. S. K KABRA ET AL (1991) ${ }^{1}$ incidence of 0.5\%-2.6\%, VIPIN ET AL (2010) ${ }^{6}$ incidence of $1.9 \%$, A M MATHEWS ET $\mathrm{AL}^{9}$ observer $2 \%$ of admissions (ST JOHNS HOSPITAL BANGLORE). The incidence is more in VIPIN ET $A L^{6}{ }^{6}$ as they have used later agglutination test and culture for isolation, detection of organism. Prior to anti-biotic era, the mortality in ABM was well above $90 \%$. In recent times the mortality has significantly come down. In the present study mortality is $33.79 \%$. The case fatality rate as observed by SWARNALI JOARDAR ET AL ${ }^{7}$ pyogenic meningitis (2011) 36.28\%, Kabra SK ET AL (1991) ${ }^{1}$ case fatality was 16\%.YUOSSEF ET AL ${ }^{8}$ case fatality ranged from $8.5 \%$ to $55 \%{ }^{150}$. The mortality rate observed VIPIN ET AL ${ }^{6}$ was 8.75\%, MATHEWS ET $\mathrm{AL}^{9}$ Mortality rate was 8.5\%. HFM FARAG ET AL ${ }^{10}$ (2005) rate was13.9.

In the present study sex distribution is Male $60.81 \%$ to Female $39.19 \%$ ratio is $1.5: 1$.The case sex distribution as observed by SWARNALI JOARDAR ET AL7 pyogenic meningitis(2011) male 60.43\%: females is $39.67 \%$, YUOSSEF ET AT ${ }^{10}$ male to female ratio is 2:1.Similar presentation has been observed in our study.

In the present study sex distribution of mortality in Male is $68 \%$ to Female $32 \%$. The case sex distribution of mortality as observed by SWARNALI JOARDAR ET AL pyogenic meningitis (2011) male $56.48 \%$ : females is $43.52 \%$, YUOSSEF ET AT ${ }^{10}$ male to female ratio is $1.8: 1$.Similar presentation has been observed in our study with male preference. Dhrubajyoti J Debnath et al ${ }^{153}$ CFR being $25 \%$ in males and $15.4 \%$ in females The CFR in males $25 \%$ was higher than in females.

Out of 74 cases $49(66.22 \%)$ are between the age group of 1Month - 1Year, 14 (18.9\%) are between the age group of 1year - 3 Year, 8 (10.8\%) are between the age group of 3year - 6 Year, 3 $(4.05 \%)$ above 6 year. Age distribution as observed by SWARNALI JOARDAR ET AL ${ }^{149}$ pyogenic meningitis (2011) $28.27 \%$ between the age group of 1Month - 1 Year,16.9\% are between the age group of 1year - 3 Year, 20.8\%) are between the age group of 3year - 6 Year, $34.03 \%$ are between the age group above 6 year.

In the pesent study More than $86 \%$ of cases are from lower or upper lower socio economic status, population was based on modified kuppuswami classification Scale 2007. SWARNALI JOARDAR ET AL ${ }^{7}$ observed rural (74.23\%) by residence. HFM FARAG ET AL ${ }^{10}$ (2005) low socioeconomic status in $96 \%$ of admissions middle class $4 \%$.

Mortality in relation to socioeconomic status in present study mortality was $100 \%$ cases of upper class as these cases have been treated outside and referred in terminal stage of disease condition.

Fever is present in $97.30 \%$ of cases in present study. In NANDITA CHINCHANKAR et al 12 $98.3 \%$ of cases, MATHEWS ET AL ${ }^{9} 86 \%$ of cases,

HFM FARAG ET AL ${ }^{10}$ (2005) 92.1\% of cases of their study. The complaint varies with age of study group if neonatal age group is considered fever is less in incidence

ALTERED SENSORIUM/COMA is present in $70 \%$ of cases in present study. NANDITA CHINCHANKAR et $\mathrm{al}^{12}$ 9.5 \% has considered loss of consciousness, HFM FARAG ET AL ${ }^{10}$ (2005). 


\section{CASE REPORT}

Seizures are present in $83.78 \%$ of cases in present study. NANDITA CHINCHANKAR ET AL $124.5 \%$ of cases, HFM FARAG ET AL ${ }^{10}$ (2005) in $64.9 \%$ of cases, P. KUMAR et al ${ }^{13} 33.3 \%$ of cases. Seizures incidence is more in present study as patient come from low socio economic back ground and from rural area, these cases have delay in accesses of medical treatment, delay in recognisition of symptoms.

Head Ache is present in $14.86 \%$ of cases, NANDITA CHINCHANKAR et al ${ }^{12}$ (2002) 95.9\% of cases, HFM FARAG ET AL ${ }^{10}$ (2005) in $55.7 \%$ of cases, JAMES A et al156 $31 \%$ there study. This is less than observed in other studies as most of the cases are less than 1 year of age who cannot express the symptom. Hypotension is present in $14.86 \%$ of cases, NANDITA CHINCHANKAR et al ${ }^{12}$ (2002) $8.43 \%$ of cases P. KUMAR et al (1993) ${ }^{13} 10.2 \%$ of cases, JAMES A et al ${ }^{14} 4 \%$ there study. This is slightly more than observed in other studies. Bleeding manifestation is present in $9.46 \%$ of cases of present study. NANDITA CHINCHANKAR et al ${ }^{12}$ (2002) $5.1 \%$ of cases. We have considered bleeding manifestation in the course of disease. This is indicative of poor prognosis of the disease.

In the present study it has been observed that Total Count less than 5000/dl are seen in $14.86 \%$ cases, Total Count 5000/dl $-15000 / \mathrm{dl}$ are seen in $55.41 \%$ cases, Total Count greater than $15000 / \mathrm{dl}$ are seen in $29.73 \%$ cases. F.A.I. RIORDAN et al(1995) ${ }^{15}$ observed in Total Count less than $5000 / \mathrm{dl}$ are seen in $13 \%$ cases, Total Count 5000/dl - 15000/dl are seen in $49 \%$ of cases, Total Count greater than $15000 / \mathrm{dl}$ are seen in $38 \%$ cases of cases of their study. 5x109 L-1 was significantly associated with death. P Value 0.02 .

In the study it has been observed that mortality and morbidity is high those cases who have less than $40 \mathrm{mg} / \mathrm{dl}$. Deaths in cases who have CSF glucose less than $40 \mathrm{mg} / \mathrm{dl}$ is 15 cases(60\%), and cases who have CSF glucose greater than $40 \mathrm{mg} / \mathrm{dl}$ is 10 cases(40\%). NANDITA CHINCHANKAR et al ${ }^{12}$ (2002) CSF sugar (mean \pm SD) $28 \pm 18$, HFM FARAG ET AL ${ }^{10}$ (2005) csf glucose $<10 \mathrm{mg} / \mathrm{dl}$ is a poor prognosticative sign.

In the study it has been observed that mortality and morbidity is high those cases who have CSF protein greater than $40 \mathrm{mg} / \mathrm{dl}$. Deaths in cases those who have CSF protein greater than 40 $\mathrm{mg} / \mathrm{dl}$ are 23 cases(92\%), and cases who have CSF protein less than $40 \mathrm{mg} / \mathrm{dl}$ is 2 cases(8\%). NANDITA CHINCHANKAR et al ${ }^{12}$ (2002) CSF proteins (mean \pm SD) 174 \pm 158 ,, MATTHIJS C. BROUWER et $\mathrm{al}^{17}(2010)$ a protein concentration of more than $2.2 \mathrm{~g}$ per liter is associated with poor prognosis.

In the study it has been observed that mortality and morbidity is high in those cases who have CSF cell count greater than 50 cell. Deaths in cases those who have CSF cell count greater than 50 cell are 17 (68\%) cases, and cases who have CSF cell count less than 50 are 8 (32\%) cases. NANDITA CHINCHANKAR et $\mathrm{al}^{12}$ (2002) CSF (mean \pm SD) $1535 \pm 2389$., ARDITI M,18 A low CSF white blood cell count with positive Gram stain is a risk factor for an un favorable outcome.

The outcome in the present study in respect to death is $33.78 \%$ and in PANDIT ET AL is $31.48 \%$. and Survival with complication is $45.95 \%$ in present study and its observed in PANDIT ET AL is $42.59 \%$. It is observer that in death and survival with complication in present study is more than the PANDIT ET AL.As we have more referral cases from peripheries as we get partially treated cases which are terminally ill. Survival without complication are $20.27 \%$ in present study and its observed in PANDIT ET AL is $25.93 \%$. It is observer that in survival without complication in present study is less than the PANDIT ET AL. As we have more referral cases from peripheries as we get partially treated cases which are terminally ill. In the present study it has been observed that out of 246 of cases suspected meningitis clinically have been sent for culture and sensitivity it has been 


\section{CASE REPORT}

observed that 32 cases are positive for culture and sensitivity of ABM and Biochemically and Cell count wise 74 cases are positive for ABM. It has been observed that pneumococci are $8(25 \%)$ cases, CPS are $3(9.38 \%)$ cases, CONS are $3(15.63 \%)$ cases, Nesseria Meningitides are $3(9.38 \%)$ Klebsiella are $4(12.50 \%)$ cases. Others- E coli \& Enterococci PSEUDOMONAS are 9(28.13\%). RAJESH BAREJA1ET AL (2013) ${ }^{19}$ Staphylococcus aureus was the commonest isolate $(30.43 \%)$ followed by Streptococcus pneumonia (14.67\%), Escherichia coli (11.41\%), Coagulase negative Staphylococcus (10.32\%), Pseudomonas aeruginosa (9.29\%), Group B Streptococcus (6.52\%) while other isolates were Klebsiella sp. (4.34\%), Enterococcus sp. (4.34\%), Neisseria meningitides (1.63\%), Acinetobacter sp. (1.08\%). Citrobacter sp., Proteus mirabilis, Listeria monocytogenes and Haemophilus influenza were also present, James A. Berkley ${ }^{15}$ CSF cultures pneumoniae 31\% $\mathrm{H}$ influenzae 24\% Nontyphoidal salmonella 2\% P aeruginosa 1\%, NANDITA CHINCHANKAR et al 12 (2002) Streptococcus pneumonia 34.03\%, Staphylococcus $1 \%$ Neisseria meningitides $17.5 \%$. There is variation in isolation of organism from different regions of the world. There is similar isolation of organism in present study and by RAJESH BAREJA1ET AL (2013).19

CONCLUSIONS: The incidence of Acute Bacterial Meningitis was 1.45\% of total Pediatric admissions. Male to Female ratio is 1.5: 1. Mortality rate was 33.79\%. Total deaths were $25(33.79 \%)$ of them17 (68\%) Males and $8(32 \%)$ are female. The incidence and Mortality were significantly high in low socio economic group. And association was statistically significant. Less the age more the incidence and mortality. Lesser the durations of symptoms more the fatal and poor outcome. Extremes of total count in CBC mortality is more. Less the CSF glucose more the mortality, who have CSF glucose less than $40 \mathrm{mg} / \mathrm{dl}$ is 15 cases (60\%). More the CSF protein more the mortality. It has been observed that mortality and morbidity is high in those cases who have CSF cell count greater than 50 cell. It has been observed that pneumococci (8/25\%), and staphylococci are the predominant cause of morbidity and mortality in the children with ABM.

\section{REFERENCES:}

1. KABRA, S.K. et al. Bacterial meningitis in India - an IJP survey. Indian journal of pediatrics, 58: 505- 511(1991).

2. SELL, S.H. Long-term sequelae of bacterial meningitis in children. Pediatric infectious disease journal, 90-93 (1983).

3. KABRA SK, Praveen Kumar, Verma IC, Mukherjee D, Chowdhary BH, Sengupta S, et al. Bacterial meningitis in India: An IJP survey. Indian J Pediatr 1991; 58: 505-511.

4. BHAT BV, VERMA IC, PURI RK, SRINIVASAN S, NALINI P. A profile of pyogenic meningitis in children. \\\\J Indian MedAssoc1991; 89: 224-227.

5. DAGBJARTSSON A, LUDVIGSSON P. Bacterial meningitis: diagnosis and initial antibiotic therapy. Pediatr Clin N Am 1987; 34: 219-230.

6. VIPIN M VASHISHTHA, **AMIT GARG, AND \#T JACOB JOHN INDIAN PEDIATRICS 986 VOLUME 48_DECEMBER 17, 2011.

7. SWARNALI JOARDAR ET AL BANGLADESH J CHILD HEALTH 2012; VOL 36 (1): 20-25J CHILD HEALTH 2012; VOL 36 (1): 20-25

8. YOUSSEF ET AL ANN EPIDIMOL 2004 14: 44-8.

9. MATHEWS ET AL Department of Paediatrics, 2, St. John's Medical College Bangalore.

10. HFM FARAG ET AL INDIAN JOURNAL OF MICROBIOLOGY 2005, 23 (2); 95-101. 


\section{CASE REPORT}

11. Dhrubajyoti J Debnath Med J DY Patil Univ [serial online] 2012 [cited 2013 Nov 22]; 5: 28-30.

12. Nandita Chinchankar et al, Indian Pediatrics 2002; 39: 914-921.

13. P. Kumar et al Bulletin of the World Health Organization, 71 (2): 183-188 (1993).

14. James A et al http://pediatrics.aappublications.org/content/114/6/e713.full.html.

15. F.A.I. RIORDAN et al(1995) ${ }^{10}$ Journal of Accident and Emergency Medicine 1995 12, 126-129.

16. Durand M.L., Calderwood S.B., Weber D.J., et al. Acute bacterial meningitis in adults: A review of 493 episodes. N. Engl. J. Med. 1993; 328: 21-8.

17. Matthijs C. Brouwer CLINICAL MICROBIOLOGY REVIEWS, July 2010, p. 467-492.

18. Arditi M, Mason EO Jr, Bradley JS, et al. Pediatrics 1998; 102: 1087-97.

19. Rajesh Bareja1et al J. Acad. Indus. Res. Vol. 1(12) May 2013.

\section{AUTHORS:}

1. G. V. Ramadevi

2. A. Venkatashetty

3. Sardar Sulthana

4. M. Suhasini

5. V. V. Ratnakar Reddy

\section{PARTICULARS OF CONTRIBUTORS:}

1. Professor, Department of Paediatrics, Kurnool Medical College, Kurnool.

2. Associate Professor, Department of Paediatrics, Kurnool Medical College, Kurnool.

3. Assistant Professor, Department of Paediatrics, Kurnool Medical College, Kurnool.
4. Assistant Professor, Department of Paediatrics, Kurnool Medical College, Kurnool.

5. Senior Resident, Department of Paediatrics, Kurnool Medical College, Kurnool.

\section{NAME ADDRESS EMAIL ID OF THE CORRESPONDING AUTHOR:}

Dr. G. V. Ramadevi, Professor, Department of Paediatrics, Kurnool Medical College / Government General Hospital, Kurnool.

E-mail: dr.ramadevigv@gmail.com

Date of Submission: 31/12/2014. Date of Peer Review: 01/01/2015. Date of Acceptance: 09/01/2015. Date of Publishing: 14/01/2015. 